\title{
COOLEY'S ANAEMIA IN A MALTESE CHILD
}

\author{
BY \\ F. S. MOONEY \\ From the British Military Hospital, Malta
}

(Received for Publication December 19, 1950)

Although almost all the earliest work upon this anaemia was done by Cooley (1927 and 1928), by Cooley and Lee (1925 and 1929), and by Cooley, Witwer, and Lee (1927) in America it soon became clear that the syndrome occurred often in the Mediterranean races. Indeed Davison and Wechsler (1939) believed that the disease originated in Greece, and had been spread to other countries by the conquering armies of Alexander the Great. The first case reported from Italy was by Ravenna and Canella in 1934. In recent years, however, examples have been reported in many other parts of the world. Fawdry (1944) has found 20 cases in Cyprus; Saracoglu (1943) reports four cases amongst Turks; one case is described in a Spanish child, by Sendrail, Lyon, and Lasserre (1936), and another in an English child by Bywaters (1938). Two have boen found in Egyptian children (Diwani, 1944), two in Bucharan Jews (Schieber, 1945), and one in a South African of European descent (Altmann, 1946). Additionally, several cases have been reported in Hindus (Malhotra and Chuttani, 1944; Mukherii, 1938; Napier, Shorten, and Das Gupta, 1939); two in Brahmins (Patel and Bhende, 1939; Dhayagude, 1944); five in Chinese (Foster, 1940; Wang and Khoo, 1940); and two in Negroes (Stiles, Manlove, and Dangerfield, 1946; Faber and Roth, 1946). It is interesting to record that one of the Chinese mentioned by Wang and Khoo, and the negro mentioned by Stiles and his colleagues were, in each case, of remote Italian ancestry.

In spite of the close proximity of Malta to the Italian peninsula, the case described here is, as far as is known, the first example of the disease to have bsen reported from Malta.

\section{Case Report}

The affected individual is the sixth child of a family of seven. Two of his sisters had previously died from a severe anaemia, and the remaining four siblings are quite healthy. The family itself is of pure Maltese ancestry.

The patient was a boy aged 2 years. His mother stated that he was unduly pale at birth, in spite of a normal and speedy confinement. Ever since, he had been lethargic, weak, and mentally retarded. When
3 months old, the enlarged spleen was noticed by his parents, and this gradually increased in size. The subsequent story is that of a relentless, progressive pallor and weakness. Enuresis and a chronic cough latterly became troublesome.

On examination the child was seen to be muddycomplexioned, pale, and irritable. His head was large, and the frontal and malar bones prominent. His eyes were deep set and the nose was short and depressed. The abdomen was protuberant, and the firm hard spleen reached down to the umbilicus. The liver was palpable two inches below the costal margin. The heart was not enlarged clinically, but a soft, systolic, apical murmur was occasionally present. Scattered rhonchi were present in the chest. The central nervous system was normal.

Haematological data obtained in May, 1948, were as follows:

R.B.C.s $3,770,000$ per c.mm.; Hb 52\%; colour index 0.69 ; W.B.C.s 14,700 per c.mm.; platelets 220,000 per c.mm.

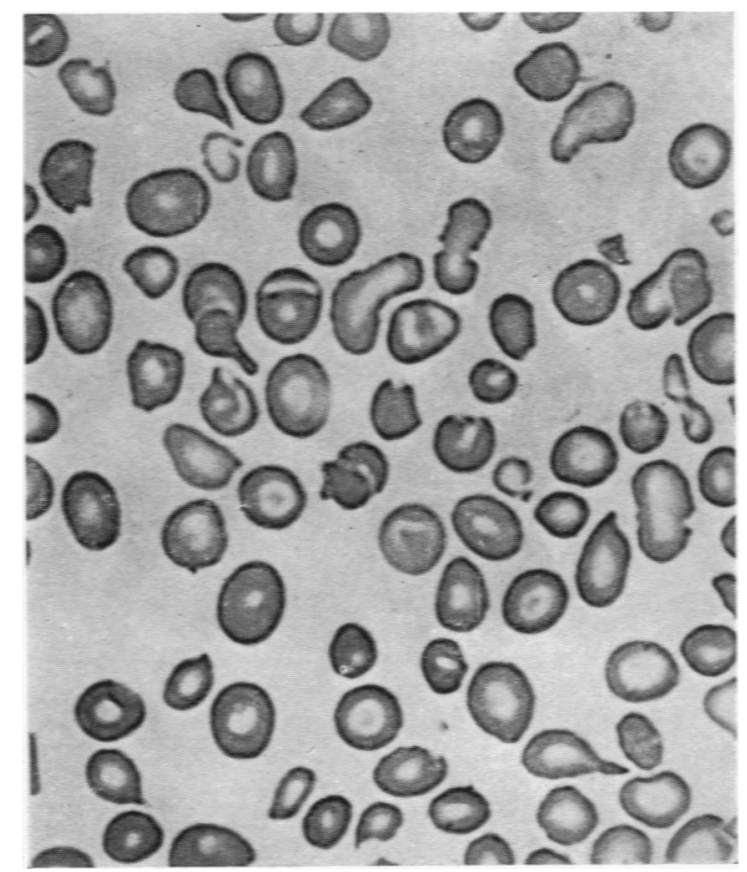

Fig. 1.-Blood film $(\times 800)$. 


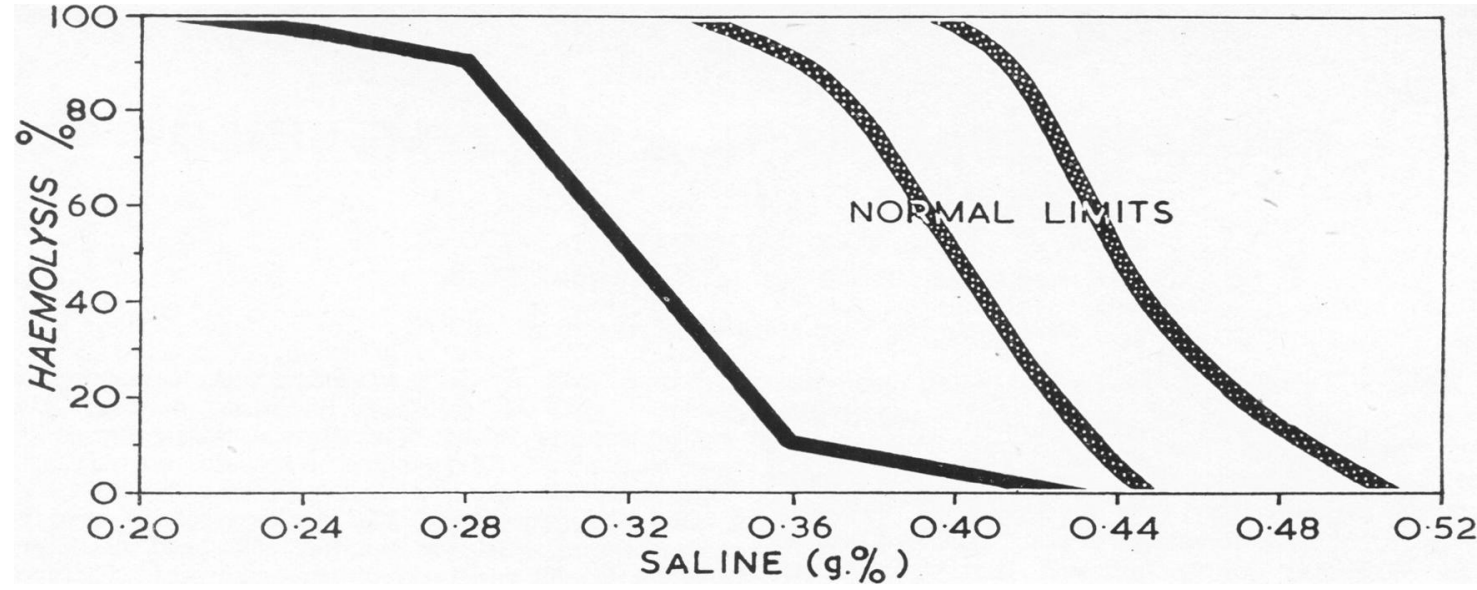

FIG. 2.-Curve of the differential fragility test.

The differential white cell count gave polymorphs $65 \%$, lymphocytes $23 \%$, monocytes $7 \%$, eosinophils $1 \%$, basophils $0 \%$, normoblasts $4 \%$.

Aniso- and poikilocytosis were marked (Fig. 1). Leptocytes were numerous and there were a few target cells.

A few thin 'hoop-type' cells with a pale rim of haemoglobin and a large central achromic area were present. No parasites were seen.

The erythrocytic indices were as follows: packed cell volume, $27 \cdot 0$; mean cell volume, $71.7 \mathrm{c} \mu$.; mean cell diameter $7 \cdot 2 \mu$.; mean cell thickness, $1.79 \mu$; mean corpuscular haemoglobin concentration, $27 \cdot 7 \%$; diameter/thickness ratio, $4 \cdot 0: 1$; standard deviation in size, $1.05 \mu$.

There were 200,000 reticulocytes per c.mm. (5.4\%), and 15,000 stipple cells per c.mm.

The serum bilirubin level was $2 \mathrm{mg}$. \%, Brucella agglutinations were negative (1/25 to $1 / 2,500)$. Schumm's test was strongly positive $(t++)$, and Napier's test for kala-azar was negative.

Urine analysis gave urobilinogen + .

The differential fragility test showed a marked increase in saline resistance (Fig. 2).

The total fat in the faeces were $22 \%$, and unsplit fat was $26 \%$ of the total fat.

Because the child did not cooperate no satisfactory pictures of the skull were obtained. Fig. 3 shows a typical increase in width of the metacarpal bones, with a thinning of the cortex.

In spite of intensive iron, vitamin, and liver therapy, no appreciative improvement was effected and the count when I last saw the child in October, 1948, was:

R.B.C.s, 3,190,000 per c.mm.; Hb, $46 \%$; colour index, 0.69; W.B.C.s, 17,200 per c.mm.; reticulocytes, $6 \cdot 8 \%$.
The differential white cell count gave polymorphs $69 \%$, lymphocytes $18 \%$, monocytes $4 \%$, eosinophils $3 \%$, normoblasts $6 \%$.

Aniso- and poikilocytosis were marked, and there were numerous leptocytes and target cells.

Differential Diagnosis. Syphilis was excluded by the Kahn reaction, and chronic malaria by the absence of parasites from numerous thick and thin blood films. Haemolytic anaemias, such as acholuric jaundice and sickle-cell anaemia, could be eliminated by the results of the fragility test, mean cell thickness, and absence of sickling in sealed preparations of blood after seven days incubation at $37^{\circ} \mathrm{C}$.

Leishmaniasis was unlikely in view of the absence on any fever, the presence of leucocytosis, a negative formol-gel test, and the absence of Leishman-Donovan
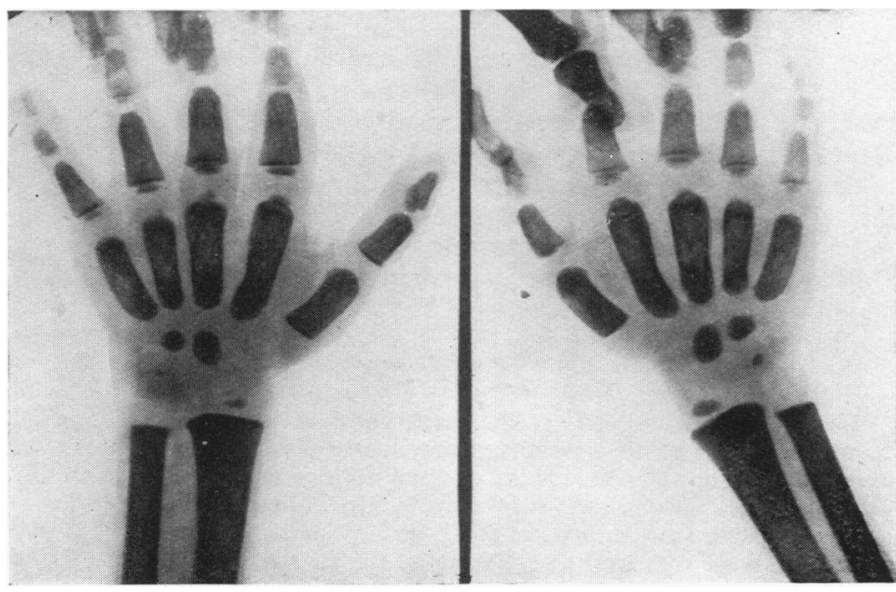

FIG. 3.-Radiograph of fore-arm and hand (E. B.). 
bodies in the blood. Additionally, the time of onset was unusually early for kala-azar.

Primary bone diseases were excluded by $x$-ray evidence, and coeliac disease by faecal fat estimation. Nutritional anaemia was unlikely in view of a negative response to vitamins, iron, and liver therapy.

Points in favour of the diagnosis of Cooley's anaemia were the absence of response to treatment, the erythrocytic resistance to saline and cell thinness, the presence of target and stipple cells, a mongoloid facies, the history of other deaths in the family from an anaemia of childhood, and the skeletal changes demonstrated by radiography, and the typical spread of the Price-Jones curve (Fig. 4).

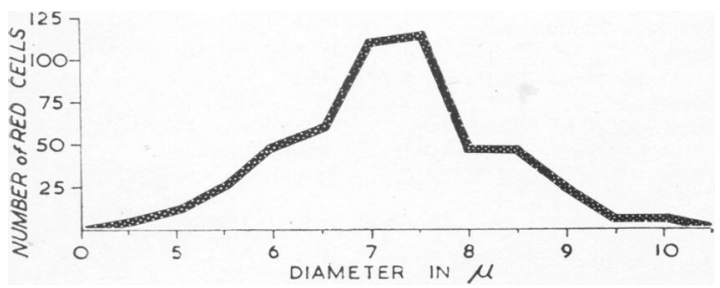

FIG. 4.-Price-Jones Curve (method of Humble and Belyavin, 1948).

\section{Discussion}

Two factors emerge from an analysis of these findings. First, the pallor which persisted from birth, and the appearance of a palpable spleen when 3 months old, indicates that the child was probably born a clinical example of the disease. Secondly, the presence of a considerable amount of methaemalbumen in the plasma, as indicated by a positive Schumm's haemochromogen test, is of significance from a haemolytic point of view. According to Fairley (1941) this pigment is formed from extracorpuscular haemoglobin when the blood is destroyed in large amounts, and its presence indicates the occurrence of an intravascular type of haemolysis. In this connexion, the similarity in the distribution of iron-positive pigment in Cooley's anaemia and in haemochromatosis is recalled (Sheldon, 1935; Nachtnebel, . 1933). In both diseases heavy deposits are found in the liver, pancreas, stomach, salivary glands, suprarenals, upper abdominal lymph nodes, and skin; conversely, very little is to be seen in either the spleen or kidneys. Also, the pigment in the liver chiefly occupies the liver cells in the peripheral half of the lobule in both conditions, whereas the Küppfer cells are strikingly empty. In Cooley's anaemia the source of this pigment almost certainly appears to be a direct result of the increased intravascular haemolysis demonstrated by Schumm's test. In haemochromatosis, however, this explanation will not suffice, for, as Sprunt (1911) has pointed out, there is no evidence of increased blood destruction in this disease. Nevertheless, the similarity of the pigment distribution in the two cases raises the speculation as to whether the iron circulating in the blood is in a closely allied or identical form in both conditions, thus accounting for the almost identical absorption by the various organs and the characteristic muddy complexions found in the two diseases (Mills, 1938).

In familial acholuric jaundice, on the other hand, Schumm's test is invariably negative (Bingold, 1930). Furthermore, the pigment distribution is entirely different, and although iron-positive material may be found in the heart, thyroid, and gastric musosa in long-standing cases, the greatest accumulation occurs in the spleen and, to a lesser extent, in the Küppfer cells of the liver (Whipple and Bradford, 1932). This disparity in the quantity of splenic pigment found in these two familial, haemolytic anaemias can be at least partially rationalized by a consideration of the physiological action of the spleen upon the morphology of erythrocytes. Singer, Miller, and Dameshek (1941), working with dogs and guinea-pigs, noted that, after either ligation of the splenic vein or splenectomy, target cells appeared in the peripheral blood. Whitby and Hynes (1935) recorded not only the appearance of target cells following splenectomy, but also an increased erythrocytic resistance to saline. As Haden and Evans (1937) have shown that increased saline resistance indicates a diminution in mean cell thickness, and Barrett (1938) that target cells are less fragile than normal, the overall effect of splenectomy on erythrocytes would appear to be a diminution in the mean cell thickness. This is supported by the observation of Bradford and Dye (1936), who recorded a reduction in M.C.T. from $2.00 \mu$ to $1.81 \mu$ in one of their cases of Cooley's anaemia after removal of the spleen. Conversely, from the accumulated evidence it would appear that under the normal conditions of stasis in the spleen (Ham and Castle, 1940; Knisely, 1936a and b) the erythrocytes undergo an increase in thickness. It is logical, therefore, to presume that cells which are spherocytic, as in acholuric jaundice, will more readily succumb to these static conditions, rupture, and be destroyed in situ. On the other hand the leptocytic cells of Cooley's anaemia will be better equipped to withstand passage through this organ, and will emerge relatively unscathed. For this reason, therefore, it is possible to understand why removal of the spleen in acholuric jaundice effects such a considerable clinical improvement, although the tendency towards spherocytosis is only slightly ameliorated (Hawksley and Bailey, 1934; Hawksley, 
1936). Similarly, as there is no pathological evidence of increased splenic haemolysis in Cooley's anaemia, removal creates no lasting improvement.

In conclusion, therefore, it would appear that the mechanism of cell destruction in these two familial haemolytic anaemias is quite different. In acholuric jaundice distribution of pigment and the effects of splenectomy indicate that the spleen is the site of the greatest erythrocytic destruction. In Cooley's anaemia, on the other hand, the absence of an excessive amount of iron in the spleen and the presence of methaemalbumen in the plasma indicates that haemolysis must be largely, if not entirely, intravascular.

\section{Summary}

Cooley's anaemia in a Maltese child is described.

The presence of methaemalbumen in the plasma is recorded, and its significance discussed.

I wish to express my gratitude to the Deputy Director of Pathology, M.E.L.F., for permission to submit this paper.

\section{REFERENCES}

Altmann, A. (1946). S. Afr. med. J., 20, 476.

Barrett, A. M. (1938). J. Path. Bact., 46, 603.

Bingold, K. (1930). Folia haemat., Lpz., 42, 192.

Bradford, W. L., and Dye, J. (1936). J. Pediat., 9, 312.

Bywaters, E. C. L. (1938). Archives of Disease in Childhood, 13, 173.

Cooley, T. B. (1927). Amer. J. Dis. Child., 33, 786. (1928). Ibid., 36, 1257. , and Lee, P. (1925). Ibid., 30, 447. , (1929). Ibid., 38, 103.

', Witwer, E. R., and Lee, P. (1927). Ibid., 34, 347. Davison, C., and Wechsler, I. S. (1939). Ibid., 58, 362. Dhayagude, R. G. (1944). Ibid., 67, 290.

Diwani, M. (1944). Archives of Disease in Childhood, $19,163$.

Faber, H. K., and Roth, B. M. (1946). J. Pediat., 28,610 .

Fairley, N. H. (1941). Ouart. J. Med., 10, 95.

Fawdry, A. L. (1944). Lancet, 1, 171.

Foster, L. P. (1940). Amer. J. Dis. Child., 59, 828.

Haden, R. L., and Evans, F. D. (1937). Arch. intern. Med., 60, 133-142.

Ham, T. H., and Castle, W. B. (1940). Proc. Amer. phil. Soc., 82, 411.

Hawksley, J. C. (1936). J. Path. Bact., 43, 565.

and Bailey, U. M. (1944). Lancet, 2, 1329.

Humble, J. G., and Belyavin, G. (1948). J. clin. Path., 1, 77.
Knisely, M. H. (1936a), Anat. Rec., 65, 23. (1936b). Ibid., 65, 131.

Malhotra, R. P., and Chuttani, P. N. (1944). Indian med. Gaz., 79, 198.

Mills, E. S. (1938). Arch. intern. Med., 62, 1004.

Mukherji, M. (1938). Indian J. Pediat., 5, 1.

Nachtnebel, E. (1933). Amer. J. Path., 9, 261.

Napier, L. E., Shorten, J. A., and Das Gupta, C. R. (1939). Indian med. Gaz., 74, 660.

Patel, N. D., and Bhende, Y. M. (1939). Indian J. Pediat., 6, 217.

Ravenna, F., and Canella, C. (1934). Policlinico (prat.), 41, 807.

Saracoglu, K. (1943). Wien. med. Wschr., 93, 217.

Schieber, C. (1945). Lancet, $2,851$.

Sendrail, M., Lyon, A., and Lasserre, J. (1936). Bull. Soc. méd. Hôp. Paris, 52, 902.

Sheldon, J. H. (1935). 'Haemochromatosis.' London.

Singer, K., Miller, E. B., and Dameshek, W. (1941). Amer. J. med. Sci., 202, 171.

Sprunt, T. P. (1911). Arch. intern. Med., 8, 75.

Stiles, M. H., Manlove, C. H., and Dangerfield, C. D. (1946). Northw. Med., Seattle, 45, 23.

Wang, C. Y., and Khoo, F. Y. (1940). Chin. med. J., $58,177$.

Whipple, G. H., and Bradford, W. L. (1932). Amer. J. Dis. Child., 44, 336.

Whitby, L. E. H., and Hynes, M. (1935). J. Path. Bact., $40,219$.

\section{APPENDIX}

The following scanty details were obtained about the two sisters, who died before this investigation.

M.B., the second child and eldest daughter, was born in 1939. She was pale, anaemic, and lethargic from birth. Her condition slowly worsened, but she was seen only by her local doctor, and was not admitted to hospital at any time. She died in 1944.

R.B., the third child and second eldest daughter, was born in 1940 . She was normal until 2 years of age, when she began to show signs of increasing pallor and weakness. Her condition slowly deteriorated, and in June, 1947, she was admitted to hospital. Her father insisted upon her discharge after a month, and she died at home in 1947. Unfortunately her hospital records could not be traced, but the following haematological report was discovered in the laboratory files.

R.B.C.s, 2,380,000 per c.mm.; Hb, 36\%； W.B.C.s, 8,200 per c.mm. A differential count gave polymorphs $29 \%$, lymphocytes $45 \%$, monocytes $9 \%$, erythroblasts $25 \%$. Aniso- and poikilocytosis were marked and there were numerous target cells and polychromatics.

Photographs of the two girls showed quite clearly that both had marked mongoloid facies. 